\title{
GAME LEARNING FISIKA “ASAH OTAK” BERBASIS ANDROID DENGAN APP INVENTOR 2
}

\author{
Rizky Parlika', Luthfiyatul 'Azizah', Anggoro Cahyo Nugroho ${ }^{3}$, Devi Anugrah Putri ${ }^{4}$ \\ Prabawani $^{5}$, Stevanus Frangky Handono ${ }^{6}$
}

Universitas Pembangunan Nasional "Veteran” Jawa Timur

rizkyparlika.if@upnjatim.ac.id ${ }^{1}, \underline{\text { luthfiazizah.if@gmail.com² }}{ }^{2}$, anggorocahyon.if@gmail.com $^{3}$, devianugrah.if@gmail.com ${ }^{4}$, stevanusfrangkyhandono.if@gmail.com ${ }^{5}$

\begin{abstract}
Serious game is one of the kind that made not only for entertaiment but also has other functions such as learning or education, training, advertising, simulation, health and others. Nowadays many games are already used as a learning or education. Educational games are usually applied based on age stages or its genre. Educational games can help to train The thinking ability and the logic skill for it players. The learning methods that using games are expected to be more interesting and understandable for it players. This paper is discussed about an educational game concept as a learning media for high school students specialized for physics subject. This game is an android-based game that expected to be directly implemented into their smartphones and can be played anywhere. This Physics Learning Game is made used App Inventor 2 (AI2).
\end{abstract}

Keywords: Serious Games, android, educational Games, App Inventor 2, Physics

\begin{abstract}
Abstrak : Serious game adalah game yang dibangun tidak hanya untuk hiburan namun memiliki fungsi lain seperti untuk pembelajaran atau edukasi, training, advertising, simulasi, kesehatan dan lainnya. Sekarang ini sudah banyak game yang digunakan sebagai pembelajaran atau edukasi. Game edukasi biasanya diterapkan berdasarkan tingkatan usia atau genre. Game edukasi dapat melatih daya pikir dan logika bagi pemainnya. Metode pembelajaran menggunakan game diharapkan menjadi lebih menarik dan mudah dipahami bagi para pemain. Tulisan ini membahas tentang sebuah konsep game edukasi sebagai media pembelajaran bagi para siswa SMA sederajat untuk mata pelajaran fisika. Game ini merupakan game berbasis android yang diharapkan dapat langsung diimplementasikan di ponsel mereka dan dapat dimainkan di manapun. Game Learning Fisika ini dibuat menggunakan App Inventor 2 (AI2). Kata kunci: serious game, android, game edukasi, App Inventor 2, fisika
\end{abstract}

\section{Pendahuluan}

Serious game adalah game yang dibangun lebih dari sekedar hiburan. Artinya dengan tetap memiliki unsur menyenangkan, serious game biasa digunakan di berbagai bidang industri lain seperti pendidikan, kesehatan, periklanan, militer, riset, dan lainnya (Adhicipta, 2017). Serious game pertama kali diungkapkan oleh Clark Abt tahun 1970 dalam bukunya yang berjudul "Serious Game" dan mulai terkenal lagi tahun 2002 ketika muncul gerakan "Serious Game" didirikan Woodrow Wilson Center for International Scholar in Washington, DC (Ririn Dwi A et al, 2013). Serious game paling banyak dikembangkan pada bidang pendidikan dengan berdasarkan tingkatan usia dan genre dari pengetahuan.

Game edukasi sangat menarik dikembangkan karena memiliki banyak kelebihan dibandingkan dengan pembelajaran secara tradisional. Kelebihannya diantaranya memiliki visualisasi yang bagus untuk meningkatkan daya ingat, permasalahan yang nyata dan mudah dipahami siswa sehingga dapat 
menarik minat belajar siswa. Selain itu juga dapat menyimpan materi pelajaran lebih lama. Game edukasi ini dapat mengembangkan daya pikir dan logika siswa karena dalam game ini mengandung unsur tantangan, ketepatan, dan nalar (Anik V, 2016).

Penggunaan smartphone semakin marak digunakan dengan berbagai fitur yang ada(Dian W dan Pratista N, 2016). Salah satunya adalah fitur game yang bermacam-macam. Game berbasis android merupakan game yang sangat laku di industri saat ini. Untuk membuat aplikasi berbasis android, banyak IDE yang bisa digunakan misalnya Android Studio. Apabila sebagai pemula masih kesulitan menggunakan Android Studio masih ada alternatif lain yaitu App Inventor 2 (AI2)( Lance A A dan Mohammad Muztaba F, 2016). Penulis memakai App Inventor 2 untuk membuat game edukasi ini.

App Inventor 2 (AI2) merupakan IDE generasi kedua dari App Inventor yang dikelola oleh Massachusetts Institute of Technology (MIT). AI2 ini masuk dalam jenis visual programming karena menggunakan block puzzle yang disusun untuk menjadi rangkaian program. AI2 memiliki 3 bagian utama yaitu designer, block editor dan android device atau emulator untuk pengujian (Endar S dan Dwi Maryono, 2017).

Dalam pembuatan game ini selain menggunakan tool App Inventor 2 juga menggunakan database. Database yang digunakan adalah PHPMyAdmin. Database ini digunakan untuk membuat login dan register user, dan membuat form untuk memasukkan soal serta jawaban.

Game pembelajaran ini mengambil studi kasus bagi siswa sekolah tingkat SMA dan sederajat. Mata pelajaran yang dibuat dalam game ini adalah fisika. Fisika ini merupakan mata pelajaran yang jarang disukai oleh para siswa karena banyaknya rumus dan materi yang ada. Fisika merupakan mata pelajaran yang memiliki isi yang kompleks yaitu konsep-konsep, rumus-rumus, perhitungan dan aplikasi dalam kehidupan sehari-hari. Game ini berisi soal-soal dari kelas X sampai kelas XII yang diharapkan bisa menjadi bahan latihan untuk menghadapi ujian-ujian atau tes. Soal-soal yang disediakan memiliki variasi yang banyak. Dengan game android ini memudahkan siswa dapat mengerjakan di mana saja. Selain itu, dalam game ini juga menampilkan high score dan kemudian dapat dibagikan ke media social lain.

Berdasarkan latar belakang di atas, maka tujuannya adalah menghasilkan media pembelajaran berupa mobile game learning berbasis android menggunakan App Inventor 2 (AI2) yang dapat digunakan sebagai pembelajaran mandiri dan sebagai peningkatan hasil belajar siswa pada materi fisika.

\section{TINJAUAN PUSTAKA}

\subsection{Serious Game}

Serious game adalah game yang dibangun memiliki fungi lebih dari sebagai hiburan. Serious game ini tetap memiliki unsur yang menyenangkan tapi juga mengandung berbagai bidang kehidupan seperti bidang training, advertising, simulasi, edukasi dan lainnya (Puji $\mathrm{H}$ et al, 2015). Pengertian lain tentang serious game adalah permainan yang melibatkan pengguna dan berkontribusi pada pencapaian tujuan yang ditetapkan.

Serious game mulai berkembang pada sepuluh tahun terakhir ini. Serious game ini paling banyak dikembangkan pada bidang Pendidikan (W. Lewis at al, 2016). Beberapa contoh Serious Game untuk Pendidikan bisnis dalam format analog misalnya Monopoly, Kanban, Power Grid, dll. Sedangkan format digital contohnya adalah Port of Call, Innov8, dan Electro City.

\subsection{Android}

Android adalah sistem operasi untuk telepon seluler berbasis Linux. Android menyediakan platform terbuka bagi para pengembang buat menciptakan aplikasi mereka sendiri untuk digunakan oleh bermacam piranti bergerak (Dian W dan Pratista N, 2016). Android adalah system operasi yang menghidupkan lebih dari satu miliar smartphone dan tablet. Sejak awal berkembangnya android ini, sudah mengalami beberapa kali mengalami perkembang versi.

Hampir semua vendor saat ini mengembangkan produknya menggunakan system operasi Android, karena peminatnya semakin banyak. Apalagi pada industri pengembang game. 


\subsection{Game Edukasi}

Game edukasi sangat menarik untuk dikembangkan pada instansi sekolah maupun lainnya. Game edukasi memiliki kelebihan dibandingkan dengan pembelajaran menggunakan metode tradisional atau konvesional.

Salah satu kelebihan utamanya adalah pada visualisasi yang menarik sehingga mudah dipahami pemain dan permasalahan yang digambarkan secara nyata sehingga memudahkan pemain dalam mengaplikasikan rumus-rumus dan konsep materi (Jamal Raiyn, 2016).

Game edukasi memiliki banyak macam biasanya didasrkan pada tingkatan usia, genre, dan tingkatan sekolah atau pengetahuan umum. Bentuk soal atau jenis soal dalam game edukasi juga bermacam-macam. Misalnya berupa kuis, soal bergambar, soal aplikasi kehidupan sehari-hari atau jenis lainnya.

Dalam soal-soal game edukasi memiliki unsur tantangan, ketepatan dan nalar. Game edukasi ini dapat melatih pemain dalam latihan soal-soal persiapan ulangan, tes dan sejenisnya.

\subsection{App Inventor}

App Inventor adalah sebuah tool untuk membuat aplikasi android, yang menyenangkan dari tool ini adalah karena berbasis visual block programming ( Gani H dan Krisnawati, 2011). Yaitu berupa block puzzle tanpa kode satupun. App Inventor sering disebut visual programming karena pengguna bisa melihat, menggunakan, menyusun dan melakukan drag and down.

App Inventor 2 adalah IDE (Integrated Development Environment) generasi kedua dari App Inventor yang dikelola oleh Massachusetts Institute of Technology (MIT). AI2 ini menggunakan block puzzle yang disusun untuk menjadi rangkaiann kode. AI2 memiliki 3 bagian utama, component designer, block editor, and android device untuk pengujian (Endar S dan Dwi Maryono, 2017).

App Inventor membuat programmer menjadi lebih mudah karena dengan menggunakan component design itu seperti sebuah prototype untuk membangun suatu aplikasi (Hwansoo Kang et al, 2015). Dengan menggunakan component design programmer dapat melihat secara nyata pembuatan menu atau tombol-tombol. Dengan menggunakan block editor, pengguna dapat melihat bagaimana kondisi dibalik aplikasi yang dibuat. Sehingga pengguna dapat mengubah dengan mudah sesuai keinginan tanpa menggunakan kode.

Jika dibandingkan dengan menggunakan software lain untuk membuat suatu aplikasi berbasis android seperti Java, pembuat game pemula lebih memilih menggunakan App Inventor sebagai alternatif lain karena lebih mudah dipahami (Radoslaw Kowalczyk et al, 2016).

\subsection{Fisika}

Fisika adalah ilmu yang mempelajari tentang alam dan unsur-unsur dasar pembentuk alam semesta, gaya-gaya yang bekerja di dalamnya, dan akibat-akibatnya yang mencakup rentang yang luas, partikel sub atom dan semua tentang alam semesta.

Dalam ilmu fisika mengandung konsep-konsep temuan ilmuwan, materi-materi pengembangan, serta pengaplikasian dalam kehidupan sehari-hari (Dio Y dan Yusman W, 2017). Ilmu fisika ini jarang disukai oleh para siswa karena dianggap memiliki kesulitas-kesulitan.

\section{Metodologi Penelitian}

Pada penelitian ini menggunakan metode penelitian dan pengembangan (Research and Development). Metode penelitian dan pengembangan adalah metode yang digunakan untuk menghasilkan suatu produk tertentu dan menguji keefektifan produk tersebut. Untuk menghasilkan 
suatu produk tertentu penelitian dilakukan dengan melakukan analisis kebutuhan dan kegunaan produk tersebut bagi lingkungan sekitar.

Penelitian ini bertujuan untuk mengembangkan media pembelajaran berupa aplikasi pembelajaran berbasis game edukasi yang berisi soal-soal fisika tingkat SMA dan sederajat. Game ini berisi soal-soal latihan yang mengandung bab-bab dari kelas X sampai kelas XII. Soal-soal berupa soal pilihan ganda dengan model soal konsep-konsep, penerapan rumus secara langsung atau penerapan dalam kehidupan sehari-hari. Game edukasi ini sangat bermanfaat bagi siswa yang akan mempersiapkan ujian-ujian atau tes atau bisa digunakan sebagai media pembelajaran mandiri untuk melatih otak dan memperbanyak latihan.

Penelitian dilakukan dengan mengkaji pada penelitian-penelitian sebelumnya serta mengkaji kebutuhan siswa tingkat SMA dan sederajat dalam memahami soal-soal fisika. Kemudian dilakukan pengembangan dengan melakukan pembuatan aplikasi game ini.

Game ini memiliki fitur login and register, pemilihan soal kelas X, XI dan kelas XII, timer saat pengerjaan soal, ditampilkan high score yang kemudian dapat dibagikan pada media sosial yang dimiliki oleh pemain.

Game ini dibuat dengan menggunakan App Inventor 2. Dengan menggunakan tool ini, lebih mudah dalam pembuatan game karena tidak perlu terlalu paham tentang koding. Pada tool ini menyediakan fitur component designer dan editor block. Component designer untuk mengatur interface dari game yang akan dibuat. Pengaturan interface yang bisa dilakukan misalnya pengaturan background, pengaturan tombol, penyisipan backsound, dan pengaturan timer.Editor Block di sini digunakan untuk melakukan pembuatan fungsi dari game ini. Misalnya pengaturan pada timer dengan waktu berapa menit, peletakan backsound di bagian tertentu, perubahan perpindahan screen, pembuatan variabel, dan pengaturan lainnya.

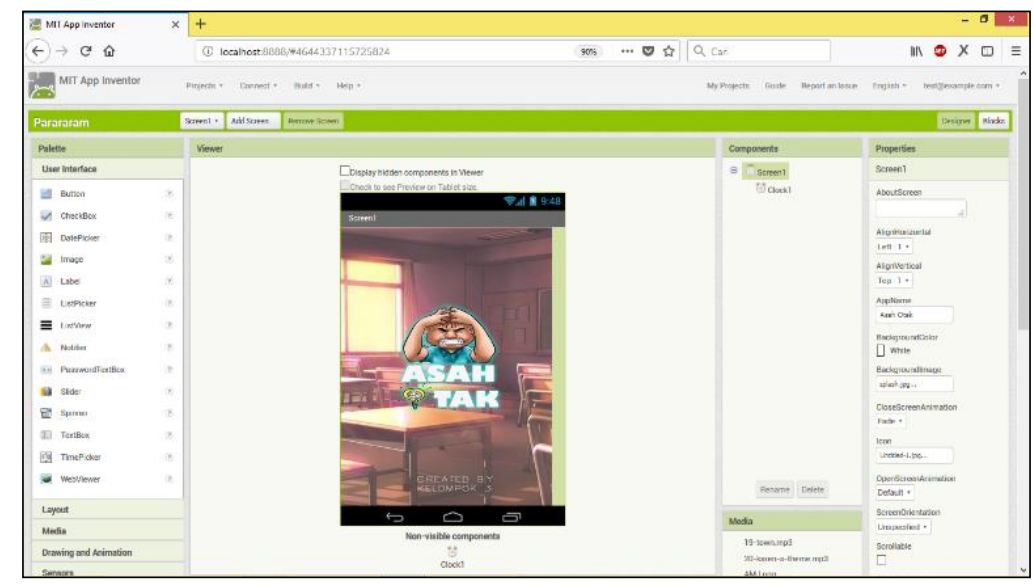

Gambar 1 Component Designer

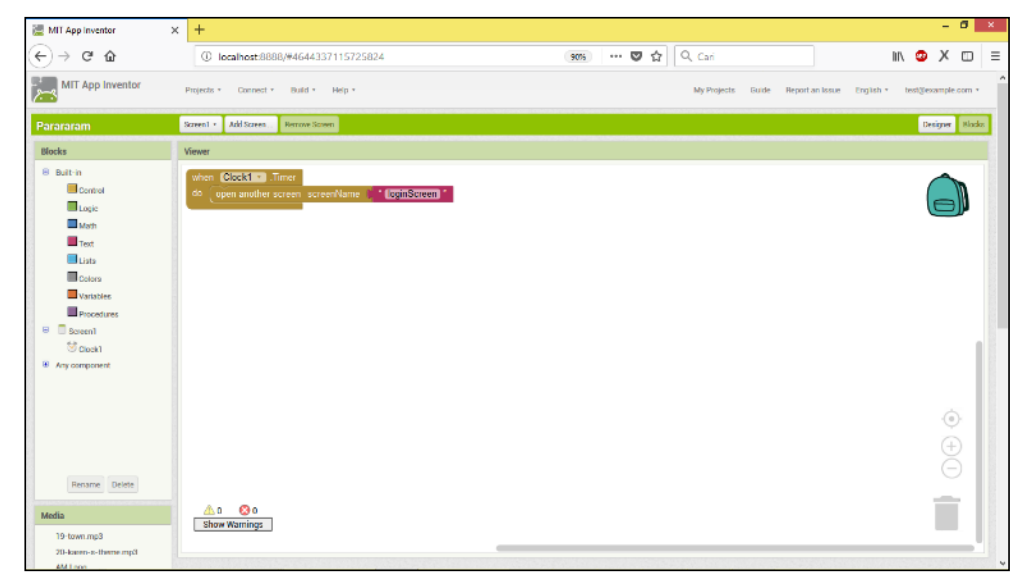


Halaman 25 - 34

\section{Gambar 2 Block Editor}

\section{HaSil Dan PEMbahasan}

Hasil dari penelitian ini adalah sebuah aplikasi game media pembelajaran fisika. Ada beberapa screen yang ada di aplikasi ini adalah splash screen, start screen, tutorial screen, selection class, play screen, exit screen.

\section{a. Splash Screen}

Splash screen ini adalah tampilan yang pertama kali muncul saat membuka game ini. Kemudian setelah 3 detik akan menuju ke screen selanjutnya.

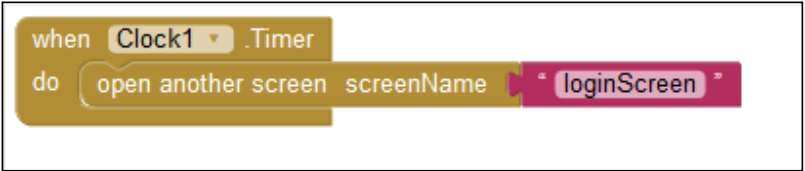

\section{Gambar 3 Block Splash Screen}

\section{b. Start Screen}

Start screen ini berisi menu dari game ini yaitu mulai bermain, peraturan, dan exit. Berikut tampilan dari screen ini.
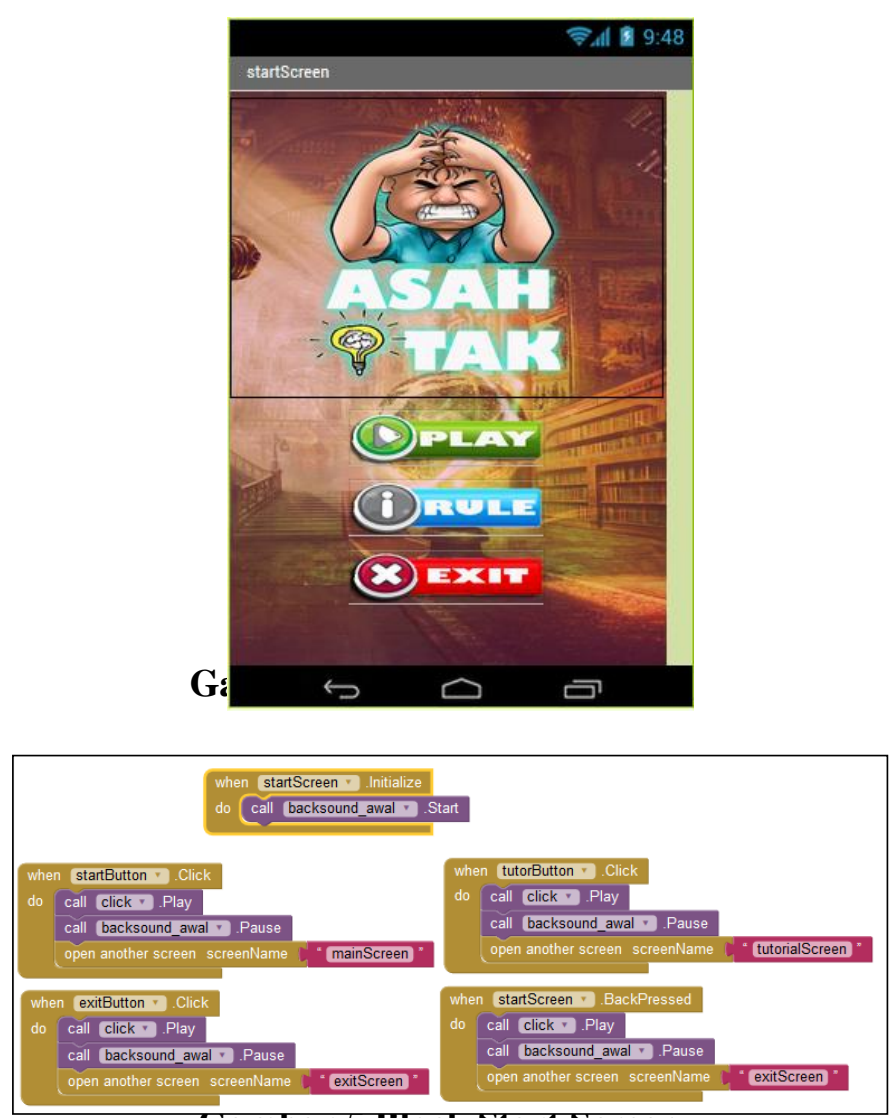

Gambar 5 Block Start Screen

\section{c. Tutorial Screen}


E-ISSN 2443-1532

Halaman 25 - 34

Pada screen ini, berisi aturan yang ada dalam permainan ini dan tutorial bermain. Berikut adalah gambar dari screen ini.

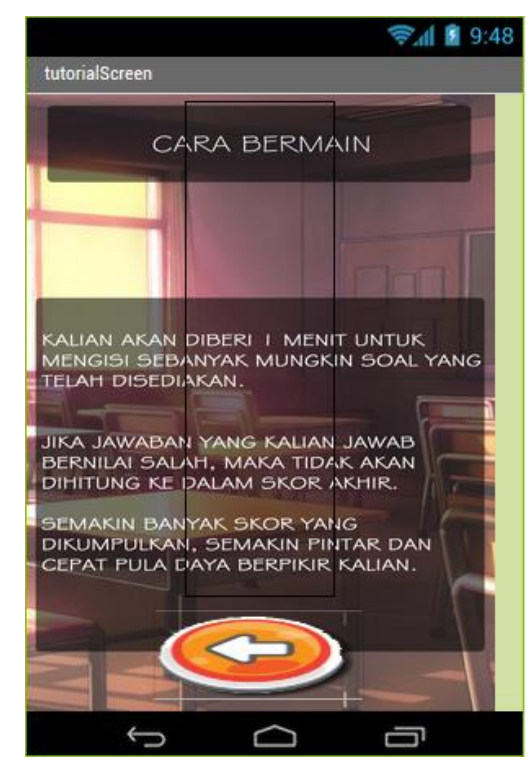

\section{Gambar 6 Design Tutorial Screen}

\section{d. Selection Screen}

Selection screen ini berisi menu untuk pemain memilih soal yang ingin dikerjakan. Pilihan soal ada kelas X, XI dan XII dengan spesifikasi UTS dan UAS.

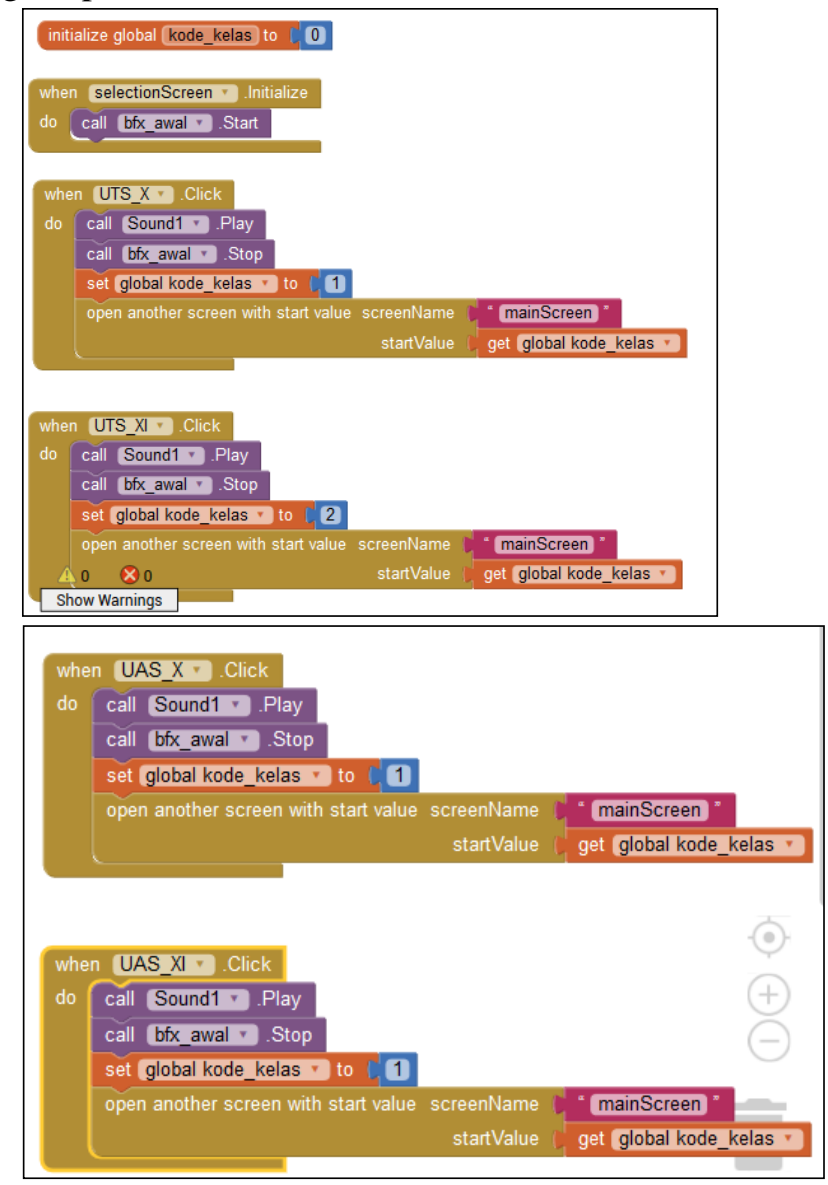

Gambar 8 Block Selection kelas XI 
Halaman 25 - 34

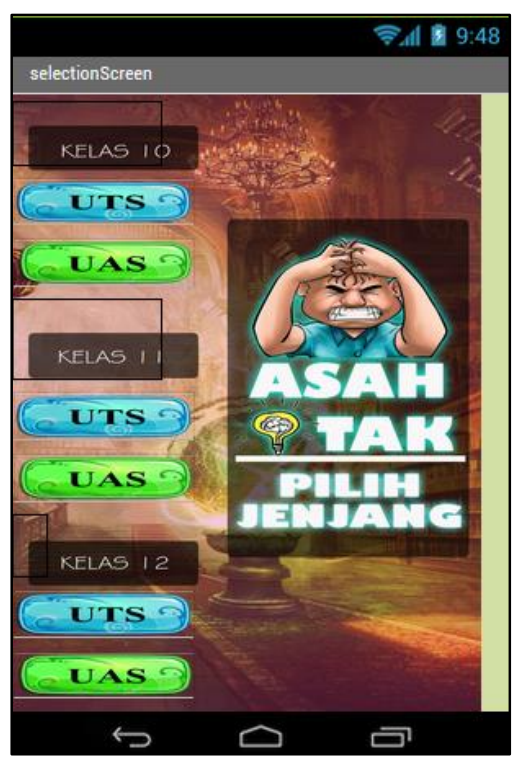

\section{Gambar 9 Design Selection Class}

\section{e. Play Screen}

Screen ini berisi papan bermain yang berisi soal-soal fisika beserta pilihan jawaban. Serta adanya timer untuk Batasan waktu pemain mengerjakan. Sehingga dari waktu tersebut akan didapat score yang dihasilkan oleh pemain. Score ini nantinya dapat dibagikan ke media social untuk diketahui orang lain sehingga dapat berlomba-lomba mengerjakan game ini.

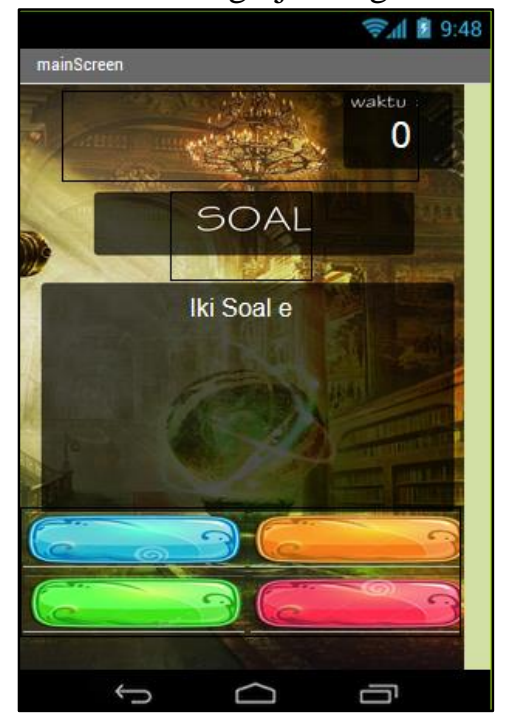

\section{Gambar 10 Design Papan Bermain}


E-jurnal: Spirit Pro Patria

Volume IV Nomor 1, Maret 2017

E-ISSN 2443-1532

Halaman 25 - 34

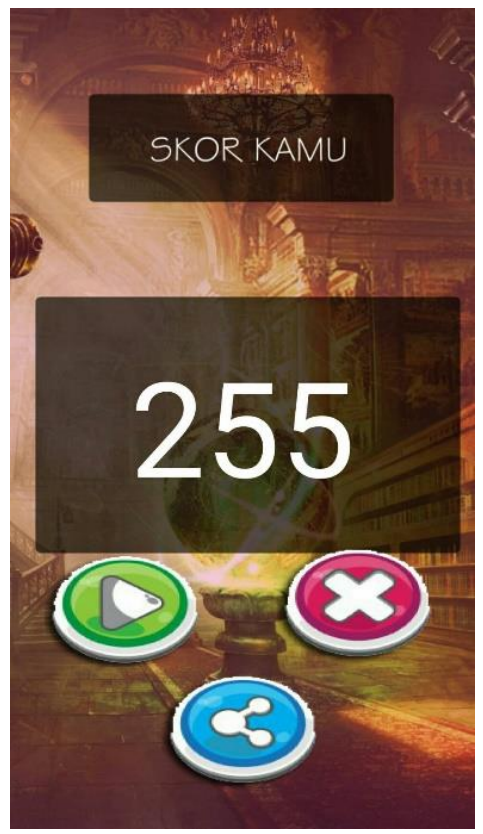

\section{f. Exit Screen}

Exit Screen ini berisi pilihan untuk keluar atau tetap berada di permainan ini.

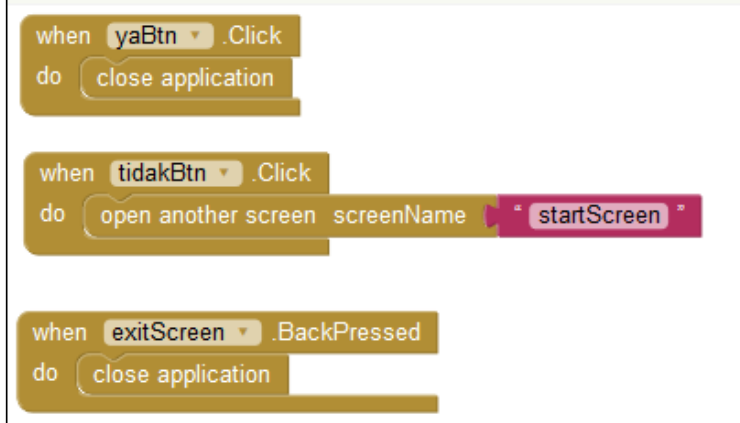

\section{Gambar 12 Block Exit Screen}

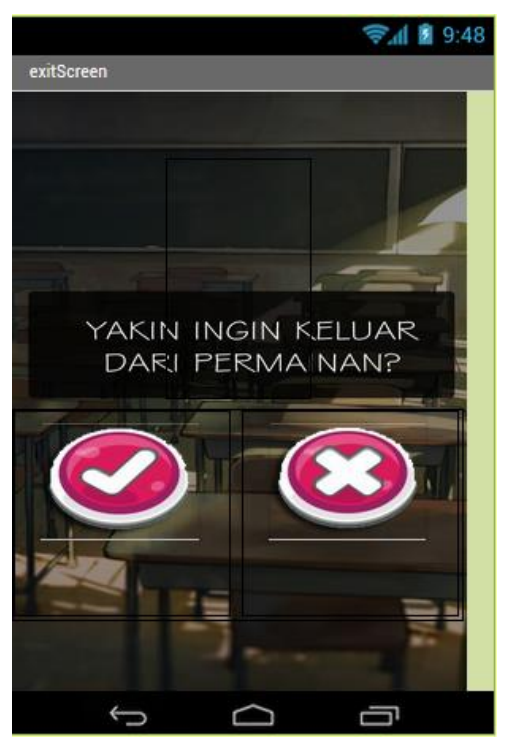




\section{Gambar 13 Design Exit Screen}

\section{KESIMPULAN DAN SARAN}

Serious game adalah game yang dibangun tidak hanya untuk hiburan saja tetapi juga bisa digunakan untuk game edukasi. Contoh implementasi dari serious game dalam bidang pendidikan adalah game "Asah Otak" ini dengan berbasis android.

Aplikasi game ini dapat digunakan sebagai media pembelajaran dalam mengasah pengetahuan tentang mata pelajaran fisika tingkat SMA dan sederajat. Selain itu aplikasi ini bermanfaat untuk latihan soal-soal fisika bagi siswa yang akan mengikuti ujian atau sejenisnya. Game ini menghasilkan tampilan yang menarik dan sederhana sehingga dapat menarik minat para siswa untuk belajar fisika.

Penggunaan App Inventor dalam pembuatan game ini sangat membantu dan lebih baik karena tidak memerlukan pemahaman yang dalam tentang pengkodean. Sehingga dapat dikatakan bahwa siapapun bisa membuat game dengan tool ini.

Aplikasi game ini tentunya belum sepenuhnya sempurna, pasti masih ada kekurangan-kekurangan yang ada. Sehingga harapannya dapat dikembangkan di kemudian waktu untuk menjadi lebih baik.

\section{DAFTAR PUSTAKA}

Adhicipta R. 2017. Kerangka Konseptual Perangcangan Serious Game untuk Mata Kuliah Strata-1 Akuntansi Perguruan Tinggi Berbasis Kerangka Kualifikasi Nasional Indonesia (KKNI). Forum Keuangan dan Bisnis Indonesia (FKBI), 6, halaman 193-200

Anik V. 2016. Game Edukasi sebagai Media Pembelajaran Pendidikan Anak Usia Dini. Jurnal INFORM 1(1), halaman 1-8

Dian W, Pratista N. 2016. Game Edukasi Berbasis Android sebagai Media Pembelajaran untuk Anak Usia Dini. Jurnal Informatika Merdeka Pasuruan (JIMP), 1(1), halaman 46-59

Dio Y, Yusman W. 2017. Pengembangan Media Pembelajaran Mobile Learning pada Platform Android Berbasis App Inventor sebagai Sumber Belajar Mandiri untuk Meningkatkan Hasil Belajar Fisika Siswa SMA N 8 Yogyakarta. Media Pengembangan Belajar. 190-196

Endar S, Dwi Maryono. 2017. Pengembangan Aplikasi Android Menggunakan Integrated Development Environment (IDE) App Inentro 2. Jurnal Ilmiah Edutic 4(1), halaman 1-12

Gani H, Krisnawati. 2011. Membangun Aplikasi Berbasis Android "Pembelajaran Psikotes" Menggunakan App Inventor. Jurnal DASI 12(4), halaman 37-42

Hwansoo Kang, Jinhyung Cho, Heecherm Kim. 2015. Application Study on Android Application Prototyping Method using App Inventor. Indian Journal of Science and Technology, 8(19), halaman $1-5$

Jamal Raiyn. 2016. Developing a Mathematic Lesson Plan based on Visual Learning Technology. I.J. Education and Management Enggineering, 4, halaman 1-9

Lance A A, Mohammad Muztaba F. 2016. Inter-App Communication between Android Apps Developed in App-Inventor and Android Studio. ACM International Conference on Mobile Software Engineering and System. IEEE

Puji H, M. Suyanto, Hanif A. 2015. Perancangan Game Design Document Serious Game Permainan Tradidional Angklek Sleman Yogyakarta. Seminar Nasional Informatika

Radoslaw Kowalczyk, Lukasz T, Kamil Z. 2016. Comparasion of App Inventor 2 and Java in Creating Personal Application for Android on Example of A Notepad. Science and Technology Journal 10, halaman 247-254 
E-jurnal: Spirit Pro Patria

Volume IV Nomor 1, Maret 2017

E-ISSN 2443-1532

Halaman 25 - 34

Ririn Dwi A, Kridan S, Ayu P, Iping S. 2013. Model Konseptual Serious Game Berdasar pada Kolaborasi Intelligent tutoring System dan Game The Sims. Konferensi Nasional Informatika 2

W. Lewis, Hannes V, Stacy M. 2016. Serious Games for Language Learning : How Much Game, How Much AI?. LudoScience 